Review

\title{
Aliskiren therapy in hypertension and cardiovascular disease: a systematic review and a meta-analysis
}

\author{
Shufang Fu' ${ }^{1, *}$, Xin Wen ${ }^{2, *}$, Fei Han ${ }^{3}$, Yin Long ${ }^{4}$ and Gaosi $\mathbf{X u}^{1}$ \\ ${ }^{1}$ Department of Nephrology, The Second Affiliated Hospital of Nanchang University, Nanchang, China \\ ${ }^{2}$ Grade 2013, School of Stomatology, Nanchang University, Nanchang, China \\ ${ }^{3}$ Kidney Disease Center, The First Affiliated Hospital, College of Medicine, Zhejiang University, Hangzhou, China \\ ${ }^{4}$ Grade 2013, The Second Clinical Medical College of Nanchang University, Nanchang, China \\ * Co-first authors contributted equally to this work
}

Correspondence to: Gaosi Xu, email: gaosixu@163.com

Keywords: aliskiren, hyperkalaemia, kidney injury, cardiovascular disease

Received: November 17, $2016 \quad$ Accepted: February 22, $2017 \quad$ Published: July 19, 2017

Copyright: Fu et al. This is an open-access article distributed under the terms of the Creative Commons Attribution License 3.0 (CC BY 3.0), which permits unrestricted use, distribution, and reproduction in any medium, provided the original author and source are credited.

\section{ABSTRACT}

The efficacy and safety of aliskiren combination therapy with angiotensin converting enzyme inhibitors (ACEIs) or angiotensin receptor blockers (ARBs) in patients with hypertension and cardiovascular disease remains attractive attention. We searched the Cochrane Central Register, the Clinical Trials Registry, EMBASE, MEDLINE and PubMed for relevant literatures up to January 2017. A total of 13 randomized controlled trials (RCTs) with 12222 patients were included in this study, and the combined results indicated that aliskiren in combination therapy with ACEIs or ARBs had remarkable effects in reducing systolic blood pressure (SBP) [weighted mean differences (WMD), $-4.20 ; 95 \%$ confidential intervals (CI) -5.44 to $-2.97 ; I^{2}$, $29.7 \%$ ] and diastolic blood pressure (DBP: WMD, $-2.09 ; 95 \%$ CI -2.90 to -1.27 ; $I^{2}, 0 \%$ ) when compared with ACEIs or ARBs monotherapy, but with significantly increased the risk of hyperkalaemia [relative risk (RR), 1.45; 95\% CI 1.28 to 1.64; $I^{2}, 10.6 \%$ ] and kidney injury ( $R R, 1.92 ; 95 \%$ CI 1.14 to $3.21 ; I^{2}, 0 \%$ ). Besides, there was no significant difference in the incidence of major cardiovascular events (RR, $0.95 ; 95 \% \mathrm{CI} 0.89$ to $1.02 ; I^{2}, 0 \%$ ) between the combined therapy and ACEIs or ARBs monotherapy. In conclusion, this meta-analysis demonstrated that aliskiren in combination therapy with ACEs/ARBs could control BP effectively, but is associated with increasing risks of hyperkalaemia and kidney injury, and have no benefit in preventing of major cardiovascular events.

\section{INTRODUCTION}

Excessive renin-angiotensin-aldosterone system (RAAS) activity is a major underlying cause of many pathological states such as hypertension, heart failure, chronic renal failure and related cardiovascular disorders. [1] Because of Ang II generation and the inhibition of the RAAS is an effective way to intervene in the pathogenesis of these disorders. [2-4] RAAS inhibitors, such as angiotensin converting enzyme inhibitors (ACEIs) and angiotensin AT1- receptor blockers (ARBs) have proved to be highly successful treatments and become the conventional strategy in these populations.
However, drugs fail to absolutely block RAAS activity with increasing the concentration of renin because they attenuate the negative feedback effect of Ang II on renin release, and such high renin levels will activate the (pro)renin receptor ((P)RR). Once activated, PRR is able to trigger the catalytic activation of the inflammatory and profibrotic prorenin/PRR/MAP kinase/ ERK 1/2 cascade. Consequently, ERK 1/2 activation results in an overexpression of the genes coding for several mediators of the mesangial cells proliferation and sclerosis, such as the transforming growth factor- $\beta 1$ (TGF- $\beta 1$ ), the plasminogen activator inhibitor-1 (PAI-1), fibronectin and collagen, which lead to the progression of renal 
damage and cardiovascular disorders along with Ang II generation, which is called "RAAS escape". Aliskiren, a direct renin inhibitor (DRI), has no effect on (pro)renin binding to its receptors, but blocks the most critical site of renin activation, which demonstrated as a considerable reduction in plasma rennin activity (PRA), and with PRA decreases significantly, Ang I, Ang II and aldosterone also decrease significantly, [5] which seems contribute to a complete cardiorenal protection.

In the past several important large-scale trials of aliskiren therapy had been conducted to evaluate the potential cardiorenal effects on morbidity and mortality. The ALTITUDE trial suggested the addition of aliskiren to standard therapy with renin-angiotensin system blockades in patients with type 2 diabetes had no effect on cardiovascular and renal events, and it may even be harmful. [6] The ASTRONAUT trial concluded aliskiren plus standard therapy did not reduce the rate of cardiovascular (CV) death or heart failure (HF) rehospitalization among hospitalizations for heart failure (HHF) patients. [7] The AQUARIUS trial indicated that aliskiren therapy did not result in improvement or slowing of the progression of coronary atherosclerosis, and has no significant effect on the risk of major cardiovascular outcomes. [8] The ATMOSPHERE trial is currently evaluating the effects of an additional treatment of aliskiren in patients with $\mathrm{HF}$ and the result is that the addition of aliskiren to enalapril led to more adverse events without an increase in benefit. [9]

The previous meta-analysis provided discordant conclusions. Weir et al. and Zheng et al. suggested there was no statistically significant difference in hyperkalaemia between aliskiren combinatiom therapy and ACEIs or ARBs monotherapy in patients with essential hypertension. [10,11] White et al. concluded that aliskiren combination therapy caused an added risk of hyperkalaemia but had no effect on renal dysfunction in essential hypertension. [12] While Harel Z et al. found that aliskiren combination therapy was related to the increased risk for hyperkalaemia, but had no effect on the acute kidney injury (AKI) in clinically diverse populations (different disease status). [13] Harel Z defined AKI as

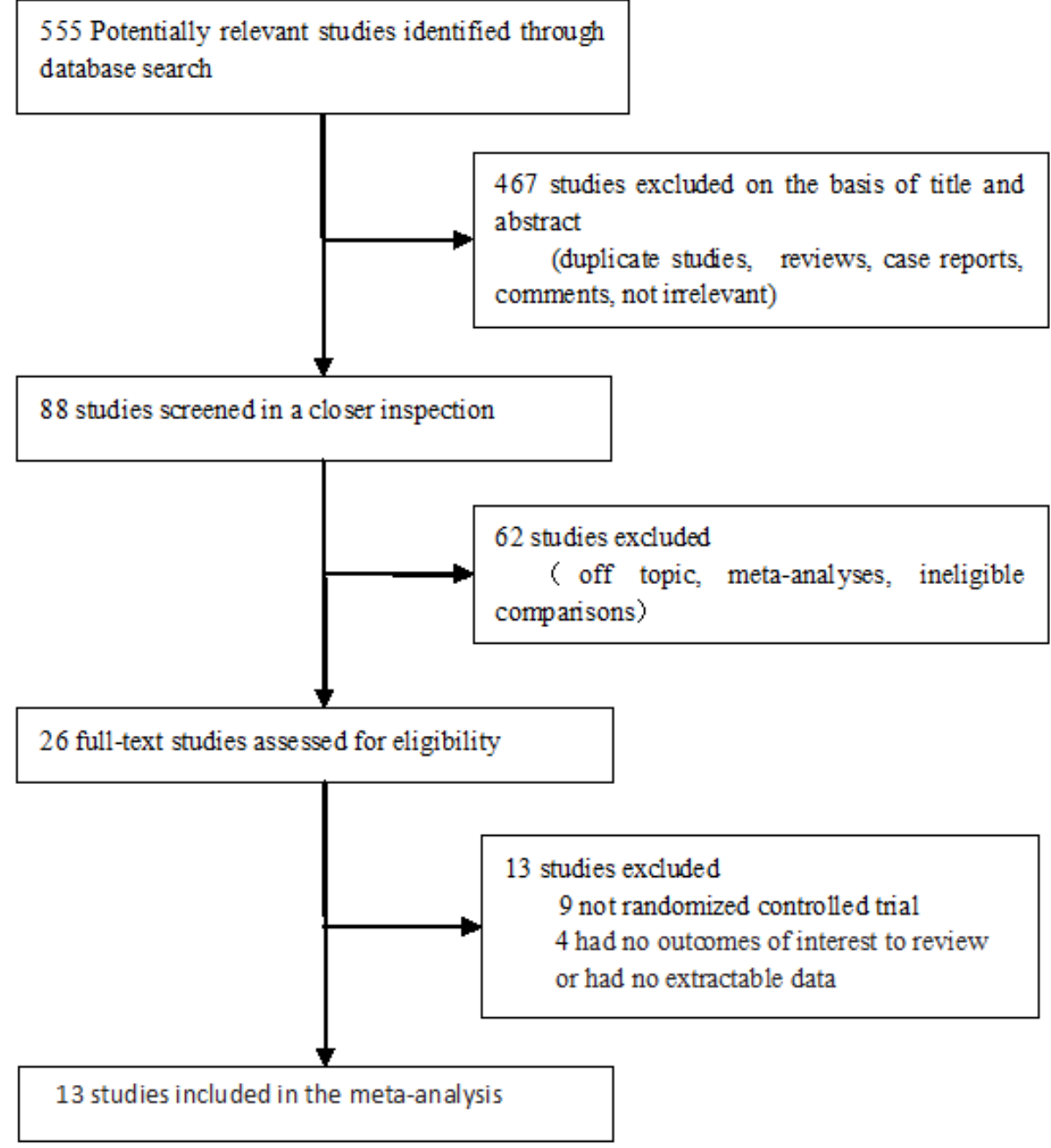

Figure 1: Flow diagram for the selection of studies inclusion in the meta-analysis 
Table 1: Characteristics of included studies

\begin{tabular}{|c|c|c|c|c|c|c|c|c|c|}
\hline Study & $\begin{array}{l}\text { Study } \\
\text { duration }\end{array}$ & $\begin{array}{l}\text { No of } \\
\text { patients }\end{array}$ & $\begin{array}{l}\text { Mean } \\
\text { Age } \\
\text { (year) }\end{array}$ & Study population & $\begin{array}{l}\text { Diabetics } \\
(\%)\end{array}$ & $\begin{array}{l}\text { GFR } \\
(\mathrm{ml} / \mathrm{min})\end{array}$ & Intervention & Control & The observed event \\
\hline $\begin{array}{l}\text { ALOFT } \\
2008\end{array}$ & $12 \mathrm{w}$ & 302 & 68 & $\begin{array}{l}\text { Hypertension with New } \\
\text { York Heart Association } \\
\text { class II to IV heart } \\
\text { failure }\end{array}$ & $31 ; 30$ & $70 ; 68$ & $\begin{array}{l}\text { Aliskiren } \\
150 \mathrm{mg} \text { plus } \\
\text { stable dose } \\
\text { of ACEIs or } \\
\text { ARBs }\end{array}$ & $\begin{array}{l}\text { Placebo plus } \\
\text { stable dose of } \\
\text { ACEIs or ARBs }\end{array}$ & $\begin{array}{l}\text { The hyperkalaemia } \\
\text { and kidney injury }\end{array}$ \\
\hline $\begin{array}{l}\text { ASTRONAUT } \\
2013\end{array}$ & $6 \mathrm{~m}$ & 1350 & 61 & $\begin{array}{l}\text { Patients hospitalized } \\
\text { for HF with reduced } \\
\text { LVEF, }\end{array}$ & NA;NA & $\mathrm{NA}$;NA & $\begin{array}{l}\text { Aliskiren } \\
300 \mathrm{mg} \text { plus } \\
\text { ACEIs } \text { or } \\
\text { ARBs }\end{array}$ & $\begin{array}{l}\text { Placebo plus } \\
\text { ACEIs or ARBs }\end{array}$ & $\begin{array}{l}\text { Cardiovascular } \\
(\mathrm{CV}) \text { death or } \mathrm{HF} \\
\text { rehospitalization } \\
\text { among } \\
\text { patients. }\end{array}$ \\
\hline $\begin{array}{l}\text { ALLAY } \\
2010\end{array}$ & $36 w$ & 306 & 59 & $\begin{array}{l}\text { Hypertension with left } \\
\text { ventricular hypertrophy }\end{array}$ & $27 ; 22$ & $83 ; 85$ & $\begin{array}{l}\text { Aliskiren } \\
\text { 300mg plus } \\
\text { losartan } \\
100 \mathrm{mg}\end{array}$ & losartan $100 \mathrm{mg}$ & $\begin{array}{l}\text { The hyperkalaemia } \\
\text { and kidney injury }\end{array}$ \\
\hline $\begin{array}{l}\text { AVANTE } \\
\text { GARDE } \\
2010\end{array}$ & $8 w$ & 550 & 63 & $\begin{array}{lr}\text { Acute } & \begin{array}{l}\text { coronary } \\
\text { without }\end{array} \\
\text { syndrome } & \text { LEV }<50 \%\end{array}$ & $21 ; 21$ & $75 ; 74$ & $\begin{array}{l}\text { Aliskiren } \\
300 \mathrm{mg} \text { plus } \\
\text { valsartan } \\
320 \mathrm{mg}\end{array}$ & valsartan320mg & $\begin{array}{l}\text { The hyperkalaemia } \\
\text { and kidney } \\
\text { injury; CV death } \\
\text { and myocardial } \\
\text { infarction }\end{array}$ \\
\hline $\begin{array}{l}\text { ASPIRE } \\
2011\end{array}$ & $36 w$ & 820 & 60 & AMI with LEVF $<45 \%$ & $23 ; 22$ & $80 ; 81$ & \begin{tabular}{|lr|}
\multicolumn{2}{|l|}{ Aliskiren } \\
300mg & plus \\
ACEIs & or \\
ARBs & \\
\end{tabular} & $\begin{array}{l}\text { Placebo plus } \\
\text { ACEIs or ARBs }\end{array}$ & $\begin{array}{l}\text { The hyperkalaemia } \\
\text { and kidney injury; } \\
\text { composite of CV } \\
\text { death }\end{array}$ \\
\hline $\begin{array}{l}\text { Drummond } \\
2011\end{array}$ & $12 \mathrm{w}$ & 363 & 56 & Hypertensive Diabetes & $100 ; 100$ & NA;NA & $\begin{array}{l}\text { Aliskiren } \\
\text { 300mg plus } \\
\text { valsartan } \\
160 \mathrm{mg}\end{array}$ & $\begin{array}{l}\text { Placebo plus } \\
\text { Valsartan } \\
160 \mathrm{mg}\end{array}$ & $\begin{array}{l}\text { The changes in } \\
\text { msDBP and msSBP; } \\
\text { the hyperkalaemia } \\
\text { and kidney injury }\end{array}$ \\
\hline $\begin{array}{l}\text { Bakris } \\
2013\end{array}$ & $8 w$ & 1143 & 55 & $\begin{array}{l}\text { Hypertension } \quad \text { with } \\
\text { type } 2 \text { diabetes }\end{array}$ & $100 ; 100$ & $95 ; 95$ & $\begin{array}{l}\text { Aliskiren } \\
\text { 300mg plus } \\
\text { valsartan } \\
\text { 320mg }\end{array}$ & valsartan $320 \mathrm{mg}$ & $\begin{array}{l}\text { The change in } \\
\text { Ambulatory blood } \\
\text { pressure; the } \\
\text { hyperkalaemia }\end{array}$ \\
\hline $\begin{array}{l}\text { ATMOSPHERE } \\
2016\end{array}$ & $36.6 \mathrm{~m}$ & 4676 & 63 & CHF with LEVF $<30 \%$ & $28 ; 28$ & $74 ; 74$ & $\begin{array}{l}\text { Aliskiren } \\
\text { 300mg plus } \\
\text { Enalapril } \\
\text { 10mg }\end{array}$ & Enalapril $10 \mathrm{mg}$ & $\begin{array}{l}\text { The death from } \\
\text { cardiovascular } \\
\text { causes } \\
\text { hospitalization for } \\
\text { heart failure. }\end{array}$ \\
\hline $\begin{array}{l}\text { Oparil } \\
2007\end{array}$ & $8 w$ & 906 & 52 & Stage I-II hypertension & NA;NA & NA;NA & \begin{tabular}{|l|} 
Aliskiren \\
300mg plus \\
valsartan \\
320mg \\
\end{tabular} & valsartan $320 \mathrm{mg}$ & $\begin{array}{l}\text { The changes in } \\
\text { msDBP and msSBP; } \\
\text { the hyperkalaemia } \\
\text { and kidney injury }\end{array}$ \\
\hline $\begin{array}{l}\text { Pool } \\
2007\end{array}$ & $8 w$ & 355 & 57 & $\begin{array}{l}\text { Mild to moderate } \\
\text { hypertension }\end{array}$ & $11 ; 7$ & NA;NA & \begin{tabular}{|l|} 
Aliskiren \\
300mg plus \\
valsartan \\
$320 \mathrm{mg}$ \\
\end{tabular} & Valsartan320mg & $\begin{array}{l}\text { The changes in } \\
\text { msDBP and msSBP }\end{array}$ \\
\hline $\begin{array}{l}\text { Uresin } \\
2007\end{array}$ & $8 w$ & 555 & 60 & $\begin{array}{l}\text { Stage I-II hypertension } \\
\text { with Diabetes mellitus } \\
\text { type 1or } 2\end{array}$ & $100 ; 100$ & NA;NA & $\begin{array}{l}\text { Aliskiren } \\
\text { 300mg plus } \\
\text { ramipril } 10 \mathrm{mg}\end{array}$ & Ramipril 10mg & $\begin{array}{l}\text { The hyperkalaemia } \\
\text { and kidney injury }\end{array}$ \\
\hline $\begin{array}{l}\text { Geiger } \\
2009\end{array}$ & $8 w$ & 620 & 53 & Hypertension & $11 ; 12$ & NA;NA & $\begin{array}{l}\text { Aliskiren } \\
\text { 300mg plus } \\
\text { valsartan } \\
\text { 320mg }\end{array}$ & Valsartan $320 \mathrm{mg}$ & $\begin{array}{l}\text { The changes in } \\
\text { msDBP and msSBP }\end{array}$ \\
\hline $\begin{array}{l}\text { Yarows } \\
2008\end{array}$ & $8 w$ & 276 & 57 & Stage 2 Hypertension & NA;NA & $\mathrm{NA} ; \mathrm{NA}$ & $\begin{array}{l}\text { Aliskiren } \\
\text { 300mg plus } \\
\text { valsartan } \\
\text { 320mg }\end{array}$ & Valsartan 320mg & $\begin{array}{l}\text { The changes in } \\
\text { msDBP and msSBP }\end{array}$ \\
\hline
\end{tabular}

Abbreviations: ACEIs or ARBs: angiotensin converting enzyme inhibitors or angiotensin receptor blockers; msSBP: mean sitting systolic BP; msDBP: mean sitting diastolic BP; GFR: glomerular filtration rate; CV death: Cardiovascular death; HF: heart failure; HHF: hospitalizations for heart failure; CHF: chronic heart failure; LEVF: left ventricular ejection fraction; m: month; w: week; NA: not available

In columns "diabetes" and "GFR" showed a series of values (e.g. 31; 30 or 70; 68), the former value is related to Intervention, and the later value is related to Control

serum creatinine concentration $>176.8 \mathrm{umol} / \mathrm{L}$ or $2.0 \mathrm{mg} /$ $\mathrm{dL}$ in their study, which might be incorrect according to the KIDGO Clinical practice guideline. The emergence of contradictory results may was due to two reasons, firstly, their research population is non -uniform; secondly, their data were too old to confer accurate and updated information. Moreover, they did not observe the efficacy of aliskiren therapy on cardiovascular events.

Considering these factors, it was thus necessary to conduct a new and comprehensive analysis including the latest published studies with large sample size. 

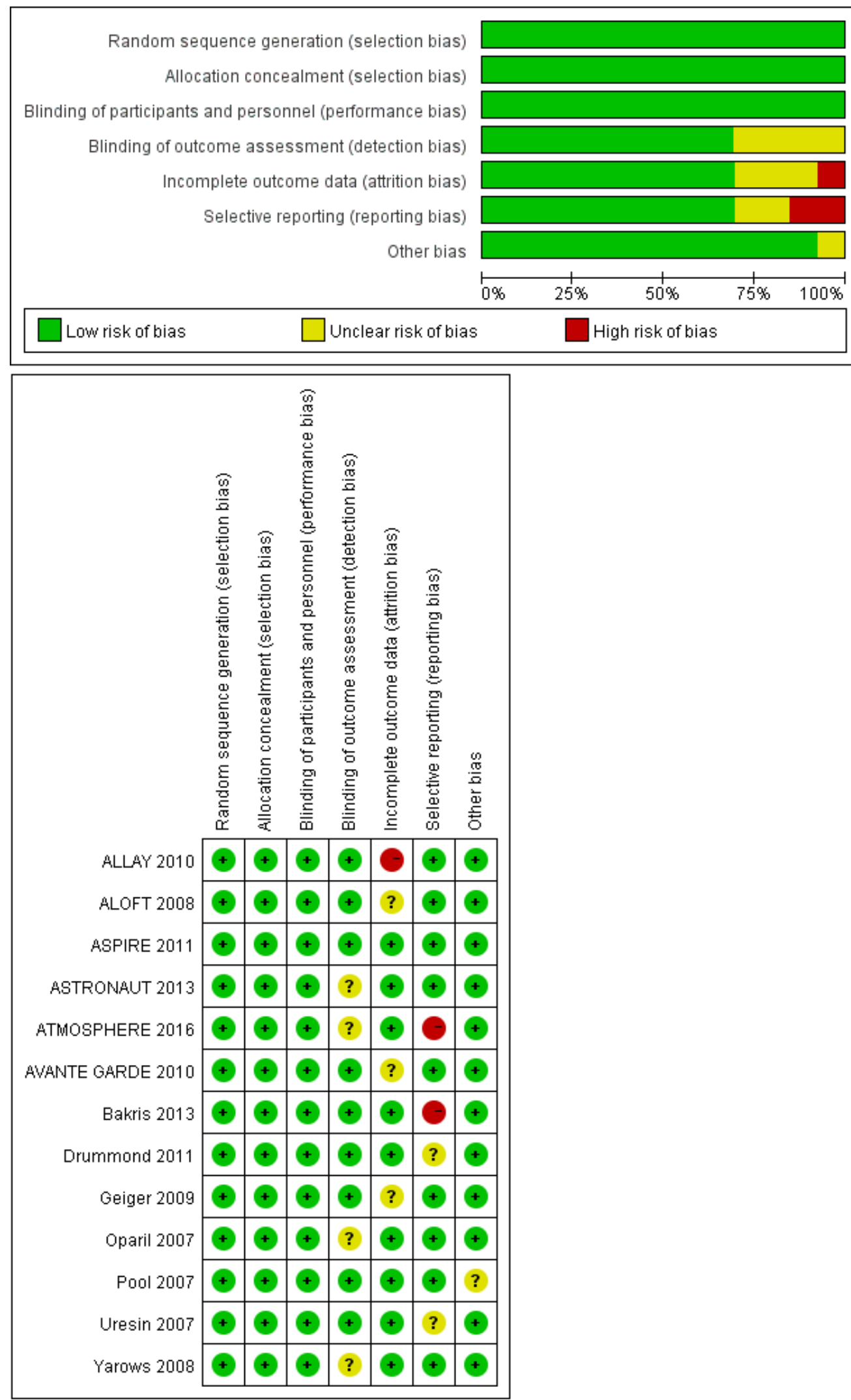

Figure 2: Risk of bias graph and risk of bias summary 
Table 2: Secondary outcomes about aliskiren combination therapy or ACEIs/ARBs monotherapy

\begin{tabular}{|l|l|l|l|l|l|l|}
\hline \multirow{2}{*}{ Study } & \multicolumn{2}{c|}{ Hyperkalaemia } & \multicolumn{2}{c|}{ Kidney injury } & \multicolumn{2}{c|}{ Cardiovascular events } \\
\cline { 2 - 7 } & \multicolumn{1}{|c|}{ Combination } & ACEI/ARB & \multicolumn{1}{c|}{ Combination } & \multicolumn{1}{c|}{ ACEI/ARB } & Combination & \multicolumn{1}{|c|}{ ACEI/ARB } \\
\hline ALLAY 2010 & $5 / 154$ & $5 / 152$ & $1 / 154$ & $1 / 152$ & NA & NA \\
\hline ALOFT 2008 & $13 / 156$ & $12 / 146$ & $11 / 156$ & $8 / 146$ & $4 / 156$ & $6 / 146$ \\
\hline ASPIRE 2011 & $55 / 423$ & $26 / 397$ & $15 / 423$ & $5 / 397$ & $39 / 422$ & $34 / 397$ \\
\hline $\begin{array}{l}\text { AVANTE GARDE } \\
2010\end{array}$ & $12 / 279$ & $8 / 268$ & $3 / 279$ & $3 / 268$ & $11 / 278$ & $13 / 268$ \\
\hline ASTRONAUT 2013 & NA & NA & NA & NA & $178 / 674$ & $182 / 686$ \\
\hline Drummond 2011 & $12 / 181$ & $10 / 177$ & $7 / 181$ & $1 / 177$ & NA & NA \\
\hline Bakris 2013 & $1 / 574$ & $2 / 565$ & NA & NA & NA & NA \\
\hline $\begin{array}{l}\text { ATMOSPHERE } \\
2016\end{array}$ & $401 / 2340$ & $291 / 2336$ & NA & NA & $770 / 2340$ & $808 / 2336$ \\
\hline Oparil 2007 & $18 / 446$ & $7 / 455$ & $2 / 446$ & $2 / 455$ & NA & NA \\
\hline Pool 2007 & $7 / 178$ & $0 / 177$ & $0 / 178$ & $0 / 177$ & NA & NA \\
\hline Uresin 2007 & $15 / 277$ & $7 / 278$ & $1 / 277$ & $1 / 278$ & NA & NA \\
\hline
\end{tabular}

Abbreviations: ACEIs or ARBs: angiotensin converting enzyme inhibitors or angiotensin receptor blockers; msSBP: mean sitting systolic BP; msDBP: mean sitting diastolic BP; GFR: glomerular filtration rate; CV death: Cardiovascular death; CHF: chronic heart failure; LEVF: left ventricular ejection fraction; m: month; w: week; NA: not available

\section{RESULTS}

\section{Study enrolment and characteristics}

We enrolled 13 studies with 12222 patients in the present analysis evaluated the efficacy and safety of aliskiren in combination therapy with ACEs/ARBs in patients with hypertension and cardiovascular disease, and Figure 1 showed the selection process. Ten studies involved in the analysis of hyperkalaemia, eight studies involved in kidney injury and four studies reported major cardiovascular events. The characteristics of the included studies and the risks of bias for RCTs were described in Table 1 and Figure 2, respectively.
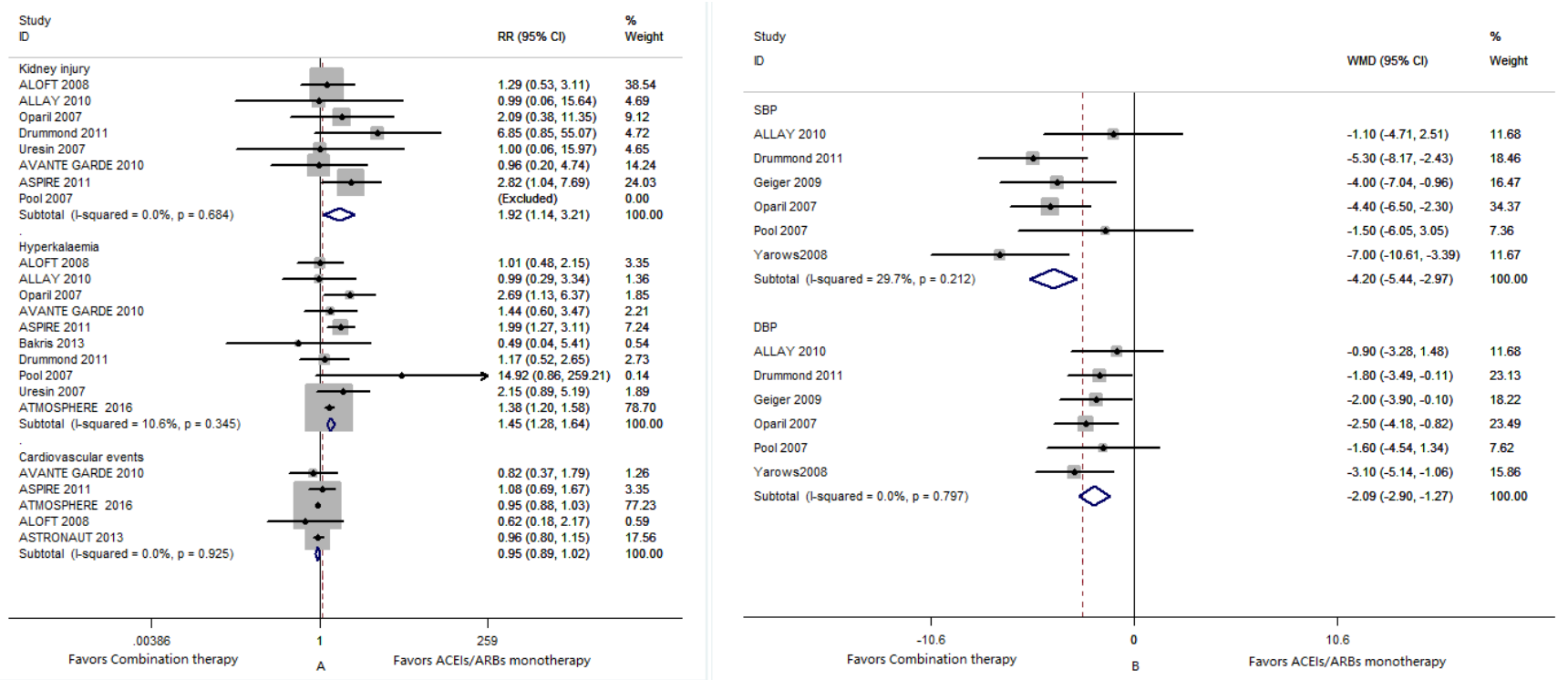

Figure 3: A: Forest plot shows the risk of secondary outcomes in aliskiren combonation therapy or ACEIs or ARBs monotherapy; B: Comparison of the effect of antihypertension between aliskiren combination therapy and ACEIs or ARBs monotherapy Abbreviations: kidney injury; ACEIs or ARBs: angiotensin converting enzyme inhibitors or angiotensin receptor blockers; SBP: systolic blood pressure; DBP: diastoblic blood pressure 


\section{Meta-analysis results}

\section{The primary outcomes}

\section{Antihypertension effects}

Six trials [14-19] involved in the analysis of antihypertension and the result suggested aliskiren in combination therapy with ACEs/ARBs was superior to ACEI or ARB monotherapy in SBP reduction (WMD, $-4.20 ; 95 \%$ CI -5.44 to $-2.97 ; I^{2}, 29.7 \%$ ) and DBP reduction (WMD, $-2.09 ; 95 \% \mathrm{CI}-2.90$ to $-1.27 ; I^{2}, 0 \%$ ) as described in Figure 3B.

\section{The secondary outcomes}

\section{Hyperkalaemia and subgroup analysis}

Ten studies $[9,14,15,17,19-24]$ reported on the outcome of hyperkalaemia (Table 2 and Figure 3A). Combination therapy was significantly associated with the risk of hyperkalaemia compared with an ACEI or an ARB monotherapy (RR $1.45 ; 95 \%$ CI 1.28 to $1.64 ; I^{2}$, $10.6 \%$ ). Among ten studies involved in hyperkalaemia, seven studies $[9,14,20-24]$ enrolled patients at high risk and three $[15,17,19]$ enrolled patients at low risk, meta-analysis found aliskiren combination therapy did significantly increase the risk for hyperkalaemia in both groups: RR in high risk patients $1.42(95 \%$ CI 1.25 to 1.61 ) and in low risk patients 2.49 (95\% CI 1.30 to 4.77), as showed in Figure 4.

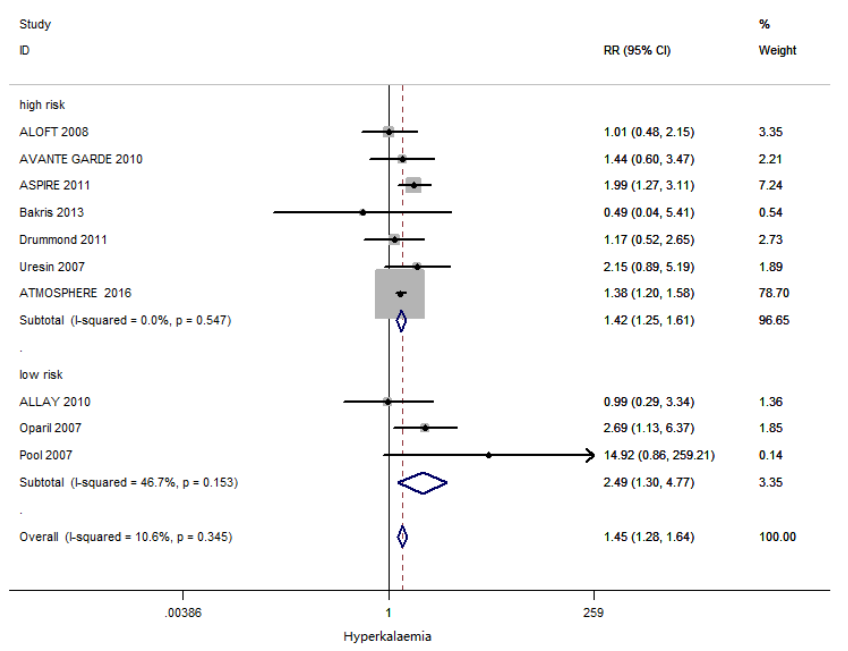

\section{Kidney injury and subgroup analysis}

Eight studies [14, 15, 17, 19, 20, 22-24] involved in kidney injury (Table 2 and Figure 3A). Combination therapy was markedly associated with the risk of kidney injury compared with an ACEI or an ARB monotherapy (RR, $1.92 ; 95 \%$ CI 1.14 to $3.21 ; I^{2}, 0 \%$ ). Among eight studies involved in kidney injury, five studies [14, 20, 22$24]$ enrolled patients at high risk and three $[15,17,19]$ enrolled patients at low risk, meta-analysis found aliskiren combination therapy did not significantly increase the risk for kidney injury in low risk group but did significantly increase in high risk group: RR in high risk patients 1.95 (95\% CI 1.12 to 3.39 ) and in low risk patients $1.71(95 \%$ CI 0.41 to 7.12 ), as showed in Figure 4.

\section{Major cardiovascular events}

Five studies [7, 9, 20, 22, 23] involved in major cardiovascular events (Table 2 and Figure 3A). There was no statistically significant difference in major cardiovascular events between the two groups (RR, 0.95; $95 \%$ CI 0.89 to $1.02 ; I^{2}, 0 \%$ ).

\section{Sensitivity analysis and publication bias}

In our analysis, we performed a sensitivity analysis to seek for the source of heterogeneity. There was a significant effect on the result of the RR and 95\% CI (Figure 5), which showed that the ATMOSPHERE study may be the source of heterogeneity in hyperkalaemia, but the heterogeneity was low $\left(I^{2}, 10.6 \%\right)$ and when the ATMOSPHERE study was excluded, there was no effects on the statistical significance. The Egger's test and Begg's funnel plot showed no evidence of publication bias for the primary outcomes and secondary outcomes.

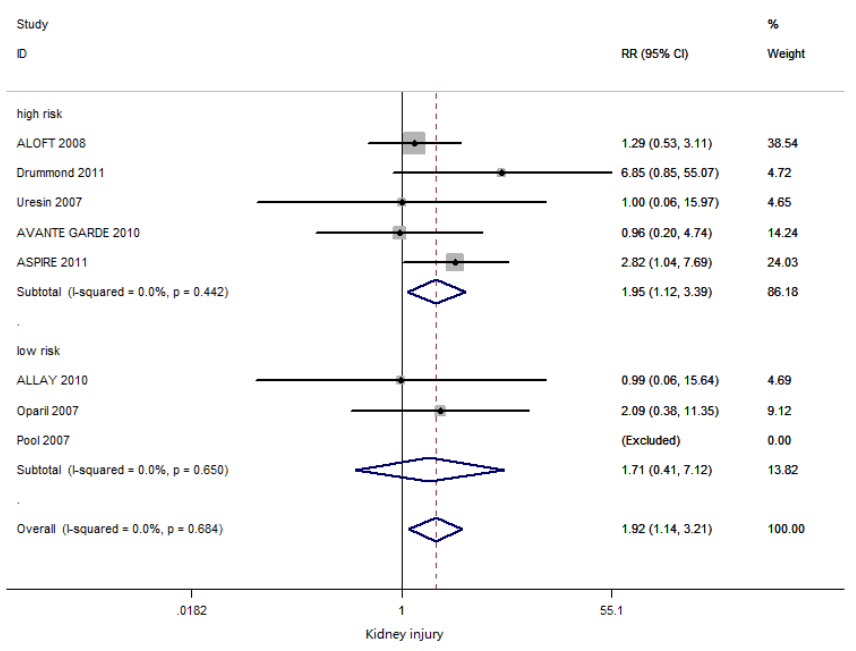

Figure 4: Subgroup analyses of hyperkalaemia and kidney injury in high risk and low risk groups 


\section{DISCUSSION}

The efficacy and safety of aliskiren has been always the focus of attention, especially when used in patients prescribed ACEIs or ARBs. The results of ASPIRE, ATMOSPHERE, ALTITUDE and ASTRONAUT suggested that such aliskiren combination therapy failed to reduce mortality and was associated with an excessive risk of adverse events, such as hyperkalaemia, hypotension, and renal failure.

RAAS inhibitors are capable of blocking aldosterone secretion from the adrenal gland because of blocking Ang II generation. Aldosterone, acting on sodium retention and urinary potassium excretion in response to increases in ambient angiotensin and extra cellular potassium concentration, thus ACEIs, ARBs and aliskiren are capable of causing hyperkalaemia. [25] In addition, RAAS blockers also influence renal hemodynamic primarily through dilation of the efferent arteriole, which lead to reduced intraglomerular pressure [26] and the decline in glomerular filtration rate (GFR), such decreases in GFR are manifested by an increase in serum creatinine levels. It seems that each class of RAAS blockers can cause hyperkalaemia and kidney injury, but this is not the case.

However, RAAS inhibitors might be expected to result in an increased incidence of hyperkalemia and kidney injury in susceptible populations such as CKD, HF and diabetes mellitus. Cause these susceptible populations have an impaired capacity for renal potassium excretion and are therefore at increased risk of developing hyperkalaemia. Moreover, in such patients, a compensatory increase in efferent, relative to afferent, arteriolar resistance occurs, which serves to increase or maintain GFR in single nephron. [25, 27] However, in patients with CKD or HF, blockade of angiotensin II production or action interferes with this compensatory response, resulting in a decrease in glomerular capillary pressure and, consequently, a reduction in GFR. [25] To be concluded, treatment of patients with failing kidneys or HF with ACEIs, ARBs or aliskiren might therefore not only cause hyperkalemia but can also cause kidney injury.

In analyses of Weir et al. White et al. and Zheng et al. enrolled patients with essential hypertension without cardiovascular disease or renal insufficiency at baseline, which might be representative of a lower-risk population. In contrast, Harel $\mathrm{Z}$ et al. included population with a broad range of baseline characteristics including lower-risk populations (essential hypertension without CKD or heart failure) and higher-risk populations (CKD, heart disease, diabetes mellitus). In our article, we included 13 trials with a total population of 12222 patients, and the study population consisted of hypertension and cardiovascular

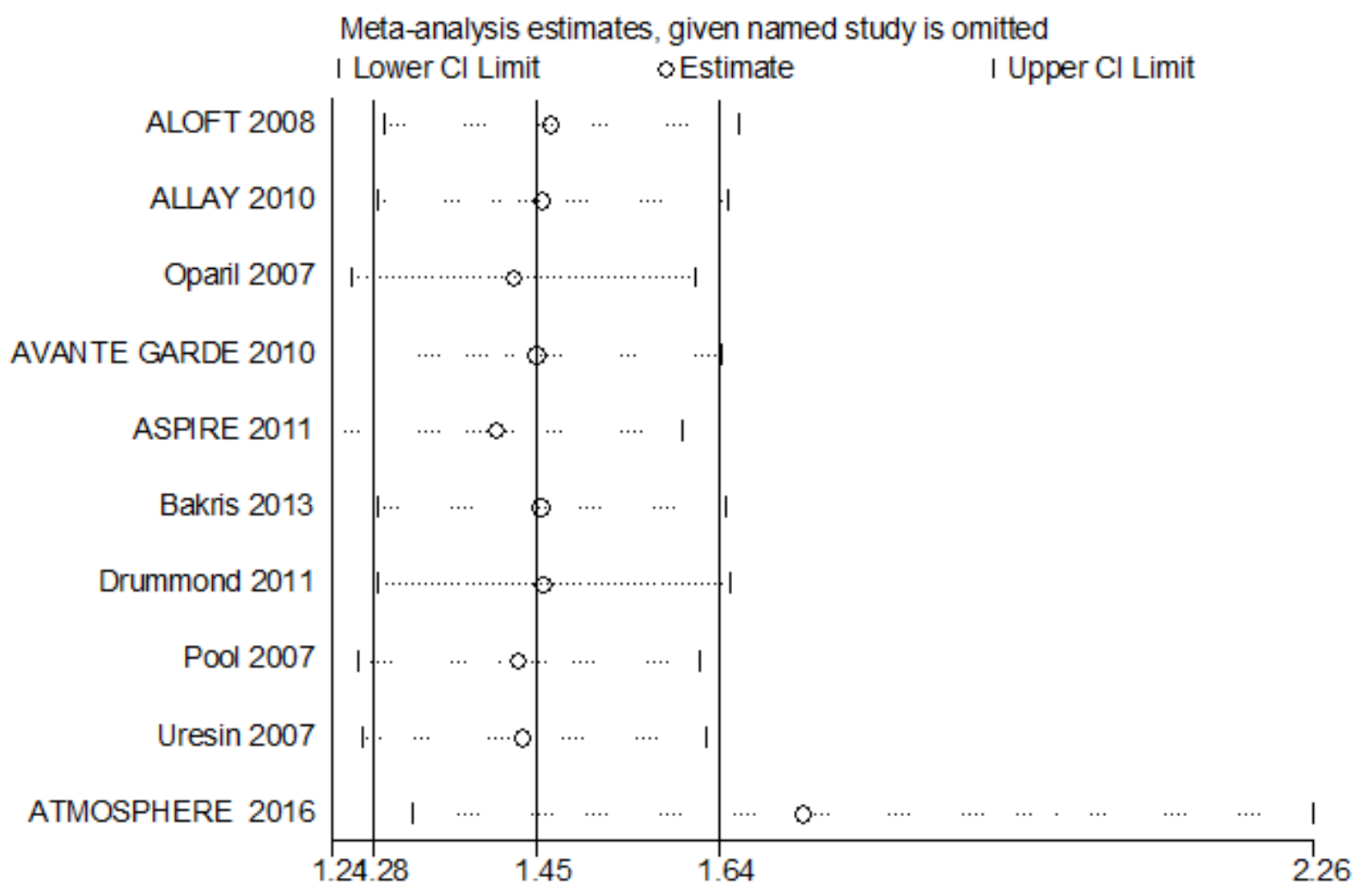

Figure 5: Sensitivity analysis of hyperkalaemia in patients with hypertension and cardiovascular disease 
diseases (such as HF and coronary disease), as described in Table 1. Because there was no heterogeneity in our outcomes (hyperkalaemia: $I^{2}, 10.6 \%$; kidney injury: $I^{2}$, $0 \%$; major cardiovascular events: $I^{2}, 0 \%$ ), and we have attempted to perform subgroup analysis to study the influence of disease types on the heterogeneity, we found that the heterogeneity would increase in both groups. Therefore we abruptly regard them as a study population in case of data loss and result bias.

According to the results of our meta-analysis, aliskiren combination therapy could control BP effectively, but with increasing risks of hyperkalaemia and kidney injury. Compared to ACEIs/ARBs monotherapy, the dual blockade of aliskirien combination therapy cause the more significant decrease in aldosterone due to the more significant blockade of Ang II generation, which should not only account for the superior antihypertension effect, but also the increased incidence of hyperkalemia.

Because the incidence of hyperkalaemia and kidney injury may be linked with the susceptible populations (high-risk populations), we stratified patients by their risk of hyperkalaemia and kidney injury into low and high risk groups and conducted subgroup analyses to discuss the effects of susceptible and non-susceptible populations. Aliskiren combination therapy did significantly increase the risk for hyperkalaemia in both groups but aliskiren combination therapy did not significantly increase the risk for kidney injury in low risk group but did significantly increase in high risk group when compared with ACEIs or ARBs. So we should take caution in combining aliskiren with an ACE inhibitor or an ARB, particularly in patients with heart disease, CKD and diabetes mellitus.

Aliskiren has been shown to be effective in lowering $\mathrm{BP}$ and affect proteinuria, left ventricular mass index and brain natriuretic peptide (BNP) levels in patients with albuminuria, LVH and HF when in combination with ACEs/ARBs, [15, 20, 28, 29] and these factors are also associated with the increased risk of cardiovascular diseases. Interestly, there was no statistically significant difference in the incidence of major cardiovascular events, in other words, aliskiren combination therapy fail to provide more effect on cardiovascular protection, maybe the overwhelming advantage on reducing $\mathrm{BP}$, proteinuria and BNP in aliskiren combination therapy, was offset by potential side effects. [7]

There are several limitations in our study. We didn't analyze the effects of dosage, duration of treatment and other antihypertension drugs on the results. Therefore for future study, the role of treatment duration and dosage should be taken into consideration before evaluating clinical outcomes.

In conclusion, this meta-analysis revealed that the use of aliskiren add-on therapy could control BP effectively but with increasing risk of hyperkalaemia and kidney injury, and have no benefits in preventing of cardiovascular events among patients with hypertension and cardiovascular disease prescribed conventional therapy with ACEIs or ARBs.

\section{MATERIALS AND METHODS}

\section{Participants, interventions and outcome measurements}

We included studies that evaluated the efficacy and safety of aliskiren in combination therapy with ACEs/ ARBs in patients with hypertension and heart failure (with a history of hypertension). In these articles, hyperkalaemia was defined as a serum potassium level of $>5.5 \mathrm{mmol} / \mathrm{L}$, and 8 out of 13 studies reported this outcome related to "a serum Creatinine concentration $>2,0 \mathrm{mg} / \mathrm{dl}$ ", the span of study duration in the 8 studies is very large (varying from 8 weeks to 36 weeks), according to the KIDGO Clinical practice guideline, "a serum Creatinine concentration > 2,0 mg/dl" cannot defined as Acute Kidney Diease (AKD), Chronic Kidney Diease (CKD) or Acute Kidney Injury (AKI), so kidney injury was abruptly defined as serum creatinine concentration $>176.8 \mathrm{umol} / \mathrm{L}$ or $2.0 \mathrm{mg} / \mathrm{dL}$, and major cardiovascular events consisted of acute myocardial infarction (AMI), stroke, resuscitated cardiac arrest, death from cardiovascular cause, and hospitalization for HF. The primary outcome was the antihypertensive effects, and the secondary outcomes were the risks of hyperkalaemia, kidney injury and major cardiovascular events.

\section{Searching strategies}

We searched the Cochrane Central Register, the Clinical Trials Registry, EMBASE, MEDLINE and PubMed for relevant literatures to Juanary 2017. Keywords include aliskiren or renin inhibitor or RAAS, hypertension, randomized controlled trial or RCT. Besides we reviewed the related research references.

\section{Inclusion and exclusion criteria}

The inclusion criteria were as follows: (a) adults with hypertension and cardiovascular disease, (b) the study design should be a RCT, (c) the study described the efficacy and safety of aliskiren combination with either ACEIs or ARBs relative to an ACEI or ARB monotherapy that provided exact value on $\mathrm{BP}$ reduction, or the incidence of hyperkalaemia, kidney injury or cardiovascular outcomes, (d) complete data available to calculate relative ratio (RR) or weighted difference (WMD) with 95\% confidence interval (CI), and (e) all dosing regimens of aliskiren, ACEIs or ARBs were considered. Exclusion criteria were as follows: (a) data from the studies could not be extracted and analyzed, (b) duplicate publications, 
and (c) non-human experimental studies.

\section{Study selection and data extraction}

Three investigators (Shufang Fu, Xin Wen, Fei Han and Yin Long) independently performed the study selection. All the disagreements were resolved by discussion. We extracted the following data from each article: first author or study group name, year of publication, number of patients, study duration, the proportion of diabetes, the Mean and standard deviation (SD) value in systolic blood pressure (SBP) and diastolic blood pressure (DBP) reduction, the occurrence rate of hyperkalaemia, kidney injury or major cardiovascular outcomes.

\section{Assessment of the risk of bias}

The risk of bias assessment tool by the Cochrane Collaboration was applied specifying the following bias domains: selection, performance, attrition, reporting bias and a judgment of low risk, unclear risk, or high risk was provided for each domain. [30]

\section{Statistical analysis}

Statistical analysis was performed by Review Manager (version 5.3) and STATA statistical software (version 12.0). The adjusted estimated effects expressed as WMD or RR with $95 \%$ CI were calculated for continuous and dichotomous data, respectively, and summarized by Forest plots. Heterogeneity among studies was estimated by Cochrane's Q-statistic and $I^{2}$ tests. A random-effect model was used when Q-test exhibits a $P<0.05$ or $I^{2}$ test shows $>50 \%$; otherwise, the fixed-effect model was selected. We performed subgroup analyses to assess for clinical heterogeneity stemming from the disease states, and we stratified patients by their risk of hyperkalemia and kidney injury into low and high risk groups, low risk was defined as patient without CKD, CAD, HF or diabetes mellitus. Inversely in high risk. Sensitivity analyses were conducted in the meta-analysis to examine the influence of an individual study. Publication bias was assessed by constructing a funnel plot and using Egger's and Begg's tests. A significant two-way $P$ value for comparison was defined as $P<0.05$.

\section{Abbreviations}

ACEIs or ARBs: angiotensin converting enzyme inhibitors or angiotensin receptor blockers; msSBP: mean sitting systolic BP; msDBP: mean sitting diastolic BP; GFR: glomerular filtration rate; $\mathrm{CV}$ death: Cardiovascular death; HF: heart failure; HHF: hospitalizations for heart failure; CHF: chronic heart failure; LEVF: left ventricular ejection fraction; m: month; w: week; NA: not available.

\section{Author contributions}

Shufang $\mathrm{Fu}$ and $\mathrm{Xi}$ Wen performed the metaanalysis, and $\mathrm{Xi}$ Wen made a great contribution to the revision of this review. Fei Han and Yin Long were responsible for the statistical analysis, Gaosi Xu prepared the manuscript and resolved the disagreement, All authors have reviewed and agreed to this information before submission.

\section{CONFLICTS OF INTEREST}

There is not any conflict of interest to report.

\section{FUNDING}

This work was supported by the National Natural Science Foundation of China (no. H0517/81560132).

\section{REFERENCES}

1. Chobanian AV, Bakris GL, Black HR, Cushman WC, Green LA, Izzo JL Jr, Jones DW, Materson BJ, Oparil S, Wright JT Jr, Roccella EJ, National Heart, Lung, and Blood Institute Joint National Committee on Prevention, Detection, Evaluation, and Treatment of High Blood Pressure, and National High Blood Pressure Education Program Coordinating Committee. The Seventh Report of the Joint National Committee on Prevention, Detection, Evaluation, and Treatment of High Blood Pressure: the JNC 7 report. JAMA. 2003; 289:2560-72.

2. Ruggenenti P, Perna A, Gherardi G, Garini G, Zoccali C, Salvadori M, Scolari F, Schena FP, Remuzzi G. Renoprotective properties of ACE-inhibition in non-diabetic nephropathies with non-nephrotic proteinuria. Lancet. 1999; 354:359-64.

3. Flather MD, Yusuf S, Køber L, Pfeffer M, Hall A, Murray G, Torp-Pedersen C, Ball S, Pogue J, Moyé L, Braunwald E, and ACE-Inhibitor Myocardial Infarction Collaborative Group. Long-term ACE-inhibitor therapy in patients with heart failure or left-ventricular dysfunction: a systematic overview of data from individual patients. Lancet. 2000; 355:1575-81.

4. Turnbull F, and Blood Pressure Lowering Treatment Trialists' Collaboration. Effects of different blood-pressurelowering regimens on major cardiovascular events: results of prospectively-designed overviews of randomised trials. Lancet. 2003; 362:1527-35.

5. Batenburg WW, de Bruin RJ, van Gool JM, Müller DN, Bader M, Nguyen G, Danser AH. Aliskiren-binding increases the half life of renin and prorenin in rat aortic 
vascular smooth muscle cells. Arterioscler Thromb Vasc Biol. 2008; 28:1151-57.

6. Parving HH, Brenner BM, McMurray JJ, de Zeeuw D, Haffner SM, Solomon SD, Chaturvedi N, Persson F, Desai AS, Nicolaides M, Richard A, Xiang Z, Brunel P, Pfeffer MA, and ALTITUDE Investigators. Cardiorenal end points in a trial of aliskiren for type 2 diabetes. N Engl J Med. 2012; 367:2204-13.

7. Gheorghiade M, Böhm M, Greene SJ, Fonarow GC, Lewis EF, Zannad F, Solomon SD, Baschiera F, Botha J, Hua TA, Gimpelewicz CR, Jaumont X, Lesogor A, et al, and ASTRONAUT Investigators and Coordinators. Effect of aliskiren on postdischarge mortality and heart failure readmissions among patients hospitalized for heart failure: the ASTRONAUT randomized trial. JAMA. 2013; 309:1125-35.

8. Nicholls SJ, Bakris GL, Kastelein JJ, Menon V, Williams B, Armbrecht J, Brunel P, Nicolaides M, Hsu A, Hu B, Fang $\mathrm{H}$, Puri R, Uno K, et al. Effect of aliskiren on progression of coronary disease in patients with prehypertension: the AQUARIUS randomized clinical trial. JAMA. 2013; 310:1135-44.

9. McMurray JJ, Dickstein K, Køber LV. Aliskiren, Enalapril, or Both in Heart Failure. N Engl J Med. 2016; 375:702.

10. Weir MR, Bush C, Anderson DR, Zhang J, Keefe D, Satlin A. Antihypertensive efficacy, safety, and tolerability of the oral direct renin inhibitor aliskiren in patients with hypertension: a pooled analysis. J Am Soc Hypertens. 2007; 1:264-77.

11. Zheng Z, Shi H, Jia J, Li D, Lin S. A systematic review and meta-analysis of aliskiren and angiotension receptor blockers in the management of essential hypertension. $\mathrm{J}$ Renin Angiotensin Aldosterone Syst. 2011; 12:102-12.

12. White WB, Bresalier R, Kaplan AP, Palmer BF, Riddell RH, Lesogor A, Chang W, Keefe DL. Safety and tolerability of the direct renin inhibitor aliskiren: a pooled analysis of clinical experience in more than 12,000 patients with hypertension. J Clin Hypertens (Greenwich). 2010; 12:765-75.

13. Harel Z, Gilbert C, Wald R, Bell C, Perl J, Juurlink D, Beyene J, Shah PS. The effect of combination treatment with aliskiren and blockers of the renin-angiotensin system on hyperkalaemia and acute kidney injury: systematic review and meta-analysis. BMJ. 2012; 344:e42.

14. Drummond W, Sirenko YM, Ramos E, Baek I, Keefe DL. Aliskiren as add-on therapy in the treatment of hypertensive diabetic patients inadequately controlled with valsartan/ HCT combination: a placebo-controlled study. Am J Cardiovasc Drugs. 2011; 11:327-33.

15. Solomon SD, Appelbaum E, Manning WJ, Verma A, Berglund T, Lukashevich V, Cherif Papst C, Smith BA, Dahlöf B, and Aliskiren in Left Ventricular Hypertrophy (ALLAY) Trial Investigators. Effect of the direct Renin inhibitor aliskiren, the Angiotensin receptor blocker losartan, or both on left ventricular mass in patients with hypertension and left ventricular hypertrophy. Circulation. 2009; 119:530-37.

16. Geiger H, Barranco E, Gorostidi M, Taylor A, Zhang $\mathrm{X}$, Xiang Z, Zhang J. Combination therapy with various combinations of aliskiren, valsartan, and hydrochlorothiazide in hypertensive patients not adequately responsive to hydrochlorothiazide alone. J Clin Hypertens (Greenwich). 2009; 11:324-32.

17. Oparil S, Yarows SA, Patel S, Fang H, Zhang J, Satlin A. Efficacy and safety of combined use of aliskiren and valsartan in patients with hypertension: a randomised, double-blind trial. Lancet. 2007; 370:221-29.

18. Yarows SA, Oparil S, Patel S, Fang H, Zhang J. Aliskiren and valsartan in stage 2 hypertension: subgroup analysis of a randomized, double-blind study. Adv Ther. 2008; 25:1288-302.

19. Pool JL, Schmieder RE, Azizi M, Aldigier JC, Januszewicz A, Zidek W, Chiang Y, Satlin A. Aliskiren, an orally effective renin inhibitor, provides antihypertensive efficacy alone and in combination with valsartan. Am J Hypertens. 2007; 20:11-20.

20. Scirica BM, Morrow DA, Bode C, Ruzyllo W, Ruda M, Oude Ophuis AJ, Lopez-Sendon J, Swedberg K, Ogorek M, Rifai N, Lukashevich V, Maboudian M, Cannon CP, et al. Patients with acute coronary syndromes and elevated levels of natriuretic peptides: the results of the AVANT GARDETIMI 43 Trial. Eur Heart J. 2010; 31:1993-2005.

21. Bakris GL, Oparil S, Purkayastha D, Yadao AM, Alessi T, Sowers JR. Randomized study of antihypertensive efficacy and safety of combination aliskiren/valsartan vs valsartan monotherapy in hypertensive participants with type 2 diabetes mellitus. J Clin Hypertens (Greenwich). 2013; 15:92-100.

22. Solomon SD, Shin SH, Shah A, Skali H, Desai A, Kober L, Maggioni AP, Rouleau JL, Kelly RY, Hester A, McMurray JJ, Pfeffer MA, and Aliskiren Study in Post-MI Patients to Reduce Remodeling (ASPIRE) Investigators. Effect of the direct renin inhibitor aliskiren on left ventricular remodelling following myocardial infarction with systolic dysfunction. Eur Heart J. 2011; 32:1227-34.

23. McMurray JJ, Pitt B, Latini R, Maggioni AP, Solomon SD, Keefe DL, Ford J, Verma A, Lewsey J, and Aliskiren Observation of Heart Failure Treatment (ALOFT) Investigators. Effects of the oral direct renin inhibitor aliskiren in patients with symptomatic heart failure. Circ Heart Fail. 2008; 1:17-24.

24. Uresin Y, Taylor AA, Kilo C, Tschöpe D, Santonastaso M, Ibram G, Fang H, Satlin A. Efficacy and safety of the direct renin inhibitor aliskiren and ramipril alone or in combination in patients with diabetes and hypertension. $\mathrm{J}$ Renin Angiotensin Aldosterone Syst. 2007; 8:190-98.

25. Toto RD. RAS blockade, hyperkalemia and AKI-look and you will find. Nat Rev Nephrol. 2012; 8:257-58. 
26. Coffman TM, Crowley SD. Kidney in hypertension: guyton redux. Hypertension. 2008; 51:811-16.

27. Toto RD, Mitchell HC, Lee HC, Milam C, Pettinger WA. Reversible renal insufficiency due to angiotensin converting enzyme inhibitors in hypertensive nephrosclerosis. Ann Intern Med. 1991; 115:513-19.

28. Parving HH, Persson F, Lewis JB, Lewis EJ, Hollenberg NK, and AVOID Study Investigators. Aliskiren combined with losartan in type 2 diabetes and nephropathy. N Engl J Med. 2008; 358:2433-46.

29. Persson F, Rossing P, Reinhard H, Juhl T, Stehouwer CD, Schalkwijk C, Danser AH, Boomsma F, Frandsen E, Parving HH. Renal effects of aliskiren compared with and in combination with irbesartan in patients with type 2 diabetes, hypertension, and albuminuria. Diabetes Care. 2009; 32:1873-79.
30. Higgins JP, Altman DG, Gøtzsche PC, Jüni P, Moher D, Oxman AD, Savovic J, Schulz KF, Weeks L, Sterne JA, and Cochrane Bias Methods Group, and Cochrane Statistical Methods Group. The Cochrane Collaboration's tool for assessing risk of bias in randomised trials. BMJ. 2011; 343:d5928. 